\title{
Mi'kmaq Language
}

National Cancer Institute

\section{Source}

National Cancer Institute. Mi'kmaq Language. NCI Thesaurus. Code C154026.

An Eastern Algonquian language spoken by the Mi'kmaq people in Canada and the United States. 